\title{
Evaluation of the decorative value of wild-grown Festuca trachyphylla (Hack.) Krajina in the southeastern part of Poland
}

Agnieszka Dąbrowska

Maria Curie-Skłodowska University Botanical Garden

Sławinkowska 3, 20-810 Lublin, Poland

\begin{abstract}
The decorative value of 24 fescue (Festuca trachyphylla) ecotypes from natural habitats in the Lublin region was assessed in the years 2004-2011. Plants with desirable ornamental characteristics were selected and the cuttings were planted in experimental plots in the Maria Curie-Skłodowska University Botanical Garden in Lublin, where they grew in uniform habitat conditions. During the study years, 18 morphological traits that determine the decorative value of grasses were analysed; 11 quantitative traits (length and number of the culm, length of the panicle, number of spikelets in the panicle, number of vegetative stems, length, width and thickness of the leaf blade, length and width of the cauline leaf and diameter of the tuft) and seven qualitative traits (plant growth habit, greenness index of the leaf blade [SPAD], winter greenness, culm colour, waxy coating on the leaf blade, flowering periods and plant condition after 8 years). The analysis of quantitative and qualitative traits demonstrated that $F$. trachyphylla is a morphologically variable species. The variability is mainly manifested in the inflorescence morphology, length of the leaf blades and number of culms, which have been statistically corroborated by the results of the ANOVA analysis. A considerable degree of variability was also exhibited by plant habit, colour of leaves and culm, wax deposits on the leaves and flowering period. The high morphological variability of this species allowed for the selection of two interesting types among the plant individuals studied, which were characterised by desirable decorative traits. The most decorative features of the selected ecotypes include the shape and colour of the leaves and the plant habit.
\end{abstract}

Key words: fescue, Festuca, morphological variability, ornamental characteristics, selection of ecotypes

\section{INTRODUCTION}

Among the numerous functions that grasses fulfil in phytocoenoses, particular importance is attached to their decorative value, which largely depends on their habit and colour (Darke 1999).

The shape of the culm, inflorescences and leaves determines the grass habit. Most species have erect shoots or slightly arching basal shoots. The mode of emergence of new shoots determines the formation of dense or loose tufts that protrude above the soil surface to a greater or lesser extent. The grass culms are divided into internodes and have leaf sheaths that expand into leaf blades of various shapes and sizes. The adaxial surface of the leaf blade is usually grooved, while the abaxial part is glossy or matte. In some species, leaves have velvety trichomes or a waxy coating, and they are arranged on the stem at various angles. The leaves are referred to as contiguous, erect, protruding, and drooping. 
A panicle or spike is located at the top of the generative shoot in the inflorescence. The shape of the spike is stable, whereas the shape of the panicle changes as the plant enters subsequent developmental stages. Spikelets as well as glume and lemma awns are the basic decorative elements of the inflorescence of this grass (Markgraf-Dannenberg 1980, Conert 1996).

The colour of the grasses is mainly determined by the level of plant dyes, particularly of chlorophyll. The chlorophyll content is related to the plant genome and may be modified in breeding. The effects of modification attempts are commonly used in the arrangement of lawns and gardens (Kozłowski et al. 2001).

Besides their decorative values, modest habitat and cultivation requirements as well as low susceptibility to diseases and pests enhance the suitability of grasses as ornamental plants. In gardens, grasses are not troublesome as their great adaptability allows them to grow in full sun or halfshade, on dry sandy slopes and in wet areas of water reservoirs (King et al. 1998).

Fescues are a separate group among lawn grasses due to their small size, round shape, subulate and often wax-coated leaves and delicate inflorescences. In garden compositions, they provide subtlety, enhance the dynamics of the arrangement, and constitute a distinct accent when planted in bigger groups. Several species from the F. ovina agg. group (Pawlus 1983), e.g. F. cinerea, F. filiformis, $F$. gautieri, $F$. glauca, $F$. ovina, and $F$. valesiaca, are popular cultivated grasses (Walters et al. 1984). $F$. trachyphylla, with its many ornamental features, is still an underrated species in this group of plants. As the naturalistic garden concept is developing, it is worth finding material for the breeding of new varieties of this species among its wild forms.

The aim of this study was to determine the decorative value of wild $F$. trachyphylla individuals growing in natural habitats in the Lublin region. The obtained results will contribute to a better understanding of the specificity of this species' development and will help in the breeding of its ornamental varieties.

\section{MATERIAL AND METHODS}

The study material included 24 ecotypes of Festuca trachyphylla (Hack.) Krajina from the natural habitats of the Lublin region. The origin and localities of the ecotypes are presented in Table 1.

In the years 2000-2002, a selection of ecotypes was carried out in the natural habitats of the Lublin region. Phenotypic variability was the basic prerequisite for selecting the individuals for further investigations. The plant selection criteria included the following traits: plant growth habit, density of tuft, height of plant, number of culms, shape and length of panicle, number of spikelets in the panicle, and colour and length of leaf blade. Plants that displayed vigorous growth and development despite adverse habitat conditions were also further chosen. An early beginning of the flowering phase, winter greenness, and symptoms of fungal infections were also taken into account.

In spring 2003, the vegetative seedlings of the selected plants were transferred from their natural localities and planted in the experimental plot of the Maria Curie-Skłodowska University Botanical Garden. When dividing the plants, it was important that each cutting had to have five vegetative shoots. 18 plants of each ecotype were planted. The experiment was conducted using the method of randomly chosen blocks in three repetitions. One repetition consisted of six plants of one individual grown at a distance of $75 \times 30 \mathrm{~cm}$.

The main study was conducted in a collection of ecotypes in the years 2004-2006 in accordance with the requirements of COBORU (Domański 1998) and the methodology used for grass ecotypes in IHAR Radzików (Prończuk 1993). In the years 2004-2009, withering inflorescences were removed in order to prevent the formation of caryopses. In 2010 and 2011, inflorescences were left throughout the vegetation period for observation of changes occurring during caryopsis maturation. The rate of plant senescence was observed throughout the study period.

The collection was set up on brown soil formed from loess $(33 \%$ of the fraction $<0.02 \mathrm{~mm})$ with $2.72 \%$ humus content and a neutral $\mathrm{pH}$ reaction in $1 \mathrm{~mol} \mathrm{KCl} \mathrm{7.1.} \mathrm{The} \mathrm{arable} \mathrm{layer} \mathrm{contained} 304$ $\mathrm{mg}$ of $\mathrm{P}_{2} \mathrm{O}_{5}, 373 \mathrm{mg}$ of $\mathrm{K}_{2} \mathrm{O}$ and $168 \mathrm{mg}$ of $\mathrm{Mg}$ per kilogram of soil.

The studies looked at 17 traits, 11 quantitative and 7 qualitative (Tabs 2 and 3), determining the value of ornamental grasses: length and number of culms, length of the panicle, number of spikelets in the panicle, number of vegetative stems, length, width and thickness of the leaf blade, length and width of the cauline leaf, diameter of the tuft (in 2006-2008), plant growth habit, the greenness index of the leaf blade (SPAD), winter greenness, culm colour, a waxy coating on the leaf blade, the flowering periods and plant condition after 8 years. Most studies were performed in the full flowering phase. Winter greenness was assessed in 
Table 1. Characteristics of the Festuca trachyphylla habitats investigated

\begin{tabular}{|c|c|c|c|c|}
\hline \multirow{2}{*}{ Habitat } & \multirow{2}{*}{ Origin } & \multirow{2}{*}{ Symbol } & \multicolumn{2}{|c|}{ Geographical coordinates } \\
\hline & & & latitude $\left({ }^{\circ} \mathrm{N}\right)$ & longitude $\left({ }^{\circ} \mathrm{E}\right)$ \\
\hline \multirow{13}{*}{ Xerothermic grassland } & Opoka Duża & $\mathrm{T}-2$ & $50^{\circ} 52^{\prime} 42^{\prime \prime}$ & $22^{\circ} 56^{\prime} 62^{\prime \prime}$ \\
\hline & Lublin & $\mathrm{T}-24$ & $51^{\circ} 16^{\prime} 52^{\prime \prime}$ & $22^{\circ} 38^{\prime} 93^{\prime \prime}$ \\
\hline & Rudnik & $\mathrm{T}-25$ & $51^{\circ} 17^{\prime} 24^{\prime \prime}$ & $22^{\circ} 36^{\prime} 13^{\prime \prime}$ \\
\hline & Ciechanki & $\mathrm{T}-27$ & $51^{\circ} 17^{\prime} 36^{\prime \prime}$ & $22^{\circ} 52^{\prime} 22^{\prime \prime}$ \\
\hline & Iłowiec & $\mathrm{T}-30$ & $50^{\circ} 50^{\prime} 05^{\prime \prime}$ & $23^{\circ} 24^{\prime} 48^{\prime \prime}$ \\
\hline & Kazimierz Dolny & $\mathrm{T}-41$ & $51^{\circ} 19^{\prime} 53^{\prime \prime}$ & $21^{\circ} 55^{\prime} 50^{\prime \prime}$ \\
\hline & Bychawa & $\mathrm{T}-43$ & $51^{\circ} 01^{\prime} 21^{\prime \prime}$ & $22^{\circ} 31^{\prime} 37^{\prime \prime}$ \\
\hline & Nałęczów & $\mathrm{T}-49$ & $51^{\circ} 17^{\prime} 26^{\prime \prime}$ & $22^{\circ} 14^{\prime} 53^{\prime \prime}$ \\
\hline & Czumów & $\mathrm{T}-50$ & $50^{\circ} 47^{\prime} 49^{\prime \prime}$ & $23^{\circ} 58^{\prime} 18^{\prime \prime}$ \\
\hline & Niedzieliska & $\mathrm{T}-51$ & $50^{\circ} 42^{\prime} 56^{\prime \prime}$ & $23^{\circ} 04^{\prime} 33^{\prime \prime}$ \\
\hline & Tarnogóra & $\mathrm{T}-65$ & $50^{\circ} 53^{\prime} 47^{\prime \prime}$ & $23^{\circ} 07^{\prime} 21^{\prime \prime}$ \\
\hline & Staw & T-96 & $51^{\circ} 12^{\prime} 21^{\prime \prime}$ & $23^{\circ} 24^{\prime} 50^{\prime \prime}$ \\
\hline & Parchatka & $\mathrm{T}-131$ & $51^{\circ} 22^{\prime} 56^{\prime \prime}$ & $21^{\circ} 49^{\prime} 96^{\prime \prime}$ \\
\hline \multirow{11}{*}{ Sand dunes } & Chotyłów & $\mathrm{T}-16$ & $52^{\circ} 00^{\prime} 46^{\prime \prime}$ & $23^{\circ} 23^{\prime} 49^{\prime \prime}$ \\
\hline & Zwierzyniec & $\mathrm{T}-23$ & $50^{\circ} 36^{\prime} 19^{\prime \prime}$ & $22^{\circ} 59^{\prime} 56^{\prime \prime}$ \\
\hline & Aleksandrów & $\mathrm{T}-26$ & $51^{\circ} 54^{\prime} 28^{\prime \prime}$ & $22^{\circ} 29^{\prime} 09^{\prime \prime}$ \\
\hline & Konstantynów & $\mathrm{T}-28$ & $51^{\circ} 12^{\prime} 43^{\prime \prime}$ & $23^{\circ} 05^{\prime} 43^{\prime \prime}$ \\
\hline & Puławy & $\mathrm{T}-29$ & $51^{\circ} 28^{\prime} 42^{\prime \prime}$ & $21^{\circ} 55^{\prime} 58^{\prime \prime}$ \\
\hline & Orchówek & $\mathrm{T}-31$ & $51^{\circ} 32^{\prime} 16^{\prime \prime}$ & $23^{\circ} 36^{\prime} 38^{\prime \prime}$ \\
\hline & Małaszewicze & $\mathrm{T}-32$ & $51^{\circ} 01^{\prime} 56^{\prime}$ & $23^{\circ} 32^{\prime} 34^{\prime \prime}$ \\
\hline & Sobibór & $\mathrm{T}-44$ & $51^{\circ} 28^{\prime} 46^{\prime \prime}$ & $23^{\circ} 39^{\prime} 46^{\prime \prime}$ \\
\hline & Krężnica Jara & $\mathrm{T}-48$ & $51^{\circ} 09^{\prime} 49^{\prime \prime}$ & $22^{\circ} 28^{\prime} 25^{\prime \prime}$ \\
\hline & Potok Wielki & $\mathrm{T}-61$ & $50^{\circ} 47^{\prime} 20^{\prime \prime}$ & $22^{\circ} 13^{\prime} 72^{\prime \prime}$ \\
\hline & Stoczek & $\mathrm{T}-141$ & $51^{\circ} 38^{\prime} 45^{\prime \prime}$ & $22^{\circ} 42^{\prime} 53^{\prime \prime}$ \\
\hline
\end{tabular}

January with the use of the IHAR 9-grade scale of the visual quality classification system (Prończuk 1993). The leaf greenness index (SPAD), which was highly correlated with the chlorophyll content, was measured using a SPAD-502 Chlorophyll Meter (Markwell et al. 1995). The central part of the leaf blade was analysed in May and August. Differences among the means of the quantitative characters were tested using a one-way analysis of variance (ANOVA) version 7.1 of the STATISTICA programme (StatSoft Inc. 2007). All of the studies were carried out in 18 repetitions for each ecotype.

\section{RESULTS AND DISCUSSION}

Ornamental grasses have a great importance in garden design or the arrangement of plant compositions; currently, native botanical species and even fodder species have been introduced (Davidson and Gobin 1998, Dąbrowska 2010).

Individuals transferred from natural, diverse habitats of the Lublin region have adapted well to the uniform conditions of the experimental plot of the Maria Curie-Skłodowska University Botanical Garden, retaining their desirable ornamental features. The change of the locality resulted in a loss of the wax coating on the leaf blades in some of the individuals, while this trait became more pronounced in others. A substantial increase in the tuft diameter and, hence, in the number of vegetative shoots, was observed (Fig. 1).

\section{Evaluation of quantitative traits}

The results of the ANOVA analysis showed a significant variability $(\mathrm{p}<0.05)$ of $F$. trachyphylla morphological traits. The highest variability was found for the length of the leaf blade, the length of the panicle, the width and length of the cauline leaf, and the number of culms (Tab. 2). The length of the leaf blade has an important effect on the plant habit. Longer leaves (over $250 \mathrm{~mm}$ ) were usually arching, while the shorter ones (below $250 \mathrm{~mm}$ ) were more rigid, subulate and erect. The morphological traits of the panicle have a substantial significance in the breeding of ornamental grasses. The panicle shape changed during the subsequent developmental 

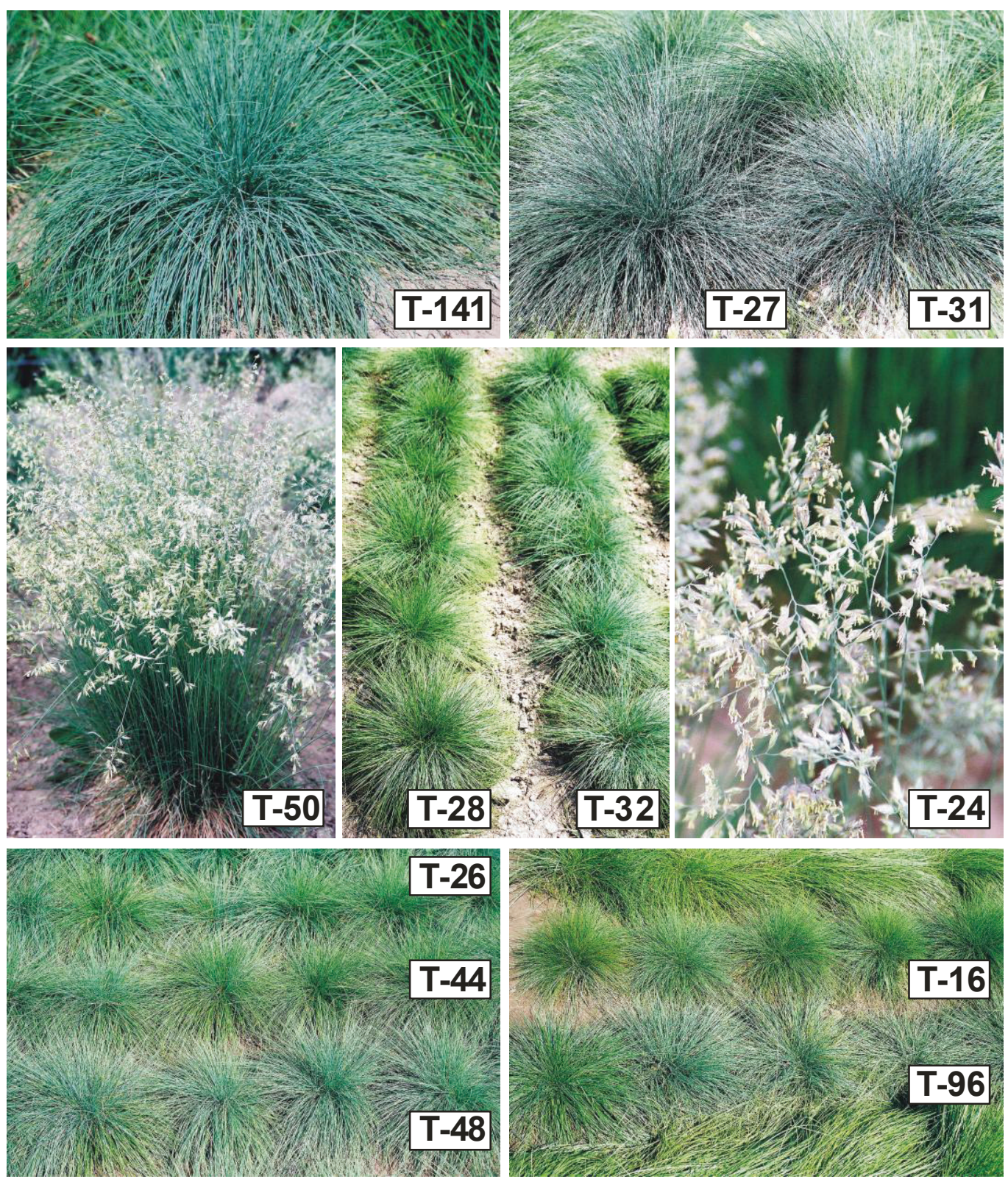

Figure 1. Habit of several individuals of Festuca trachyphylla in the collection of the Maria Curie-Skłodowska University Botanical Garden

stages. In the flowering stage, the panicles were erect and loose, and during grain ripening, they were compact and slender. The shorter panicles were round-shaped, while the longer ones were oblongto-oval. The caryopses did fall out, therefore mature inflorescences are a decorative element in the summer or they can be used in plant compositions after harvesting. On average, the inflorescences contained above 27 spikelets. The number of culms had an effect on tuft density. Individuals producing many culms formed dense tufts and appeared as a distinct decorative element during the flowering stage. Individuals with a low number of culms seemed very delicate; hence, they could be useful in smaller gardens. Erect culms were a constant feature of all individuals. Despite the high variability of the cauline leaf within the species, they did not have a high decorative value. They were arranged in two on glabrous and coriaceous culms. They reached the highest decorative value during the flowering period, but they soon withered.

The other quantitative traits were more constant for this species (Tab. 2). The mean length of the culm was almost $500 \mathrm{~mm}$; therefore, F. trachyphylla may be classified as a short perennial. A tuft with a diameter of $100 \mathrm{~mm}$ comprised, on average, 487 vegetative stems. The shape of the leaf blades is a significant issue in the breeding of ornamental grasses (Prończuk 1993). F. trachyphylla is a fine- 
Table 2. The range for the 11 quantitative characteristics and the results of the ANOVA analysis of variance

\begin{tabular}{lccc}
\hline Character & $F(\mathrm{p}<0.05)$ & $\begin{array}{c}\text { F. trachyphylla } \\
\text { Min-max }\end{array}$ & Mean \\
\hline Length of leaf blade (mm) & 31.52 & $132.0-309.0$ & 223.0 \\
Length of panicle (mm) & 24.82 & $68.5-153.3$ & 99.8 \\
Width of cauline leaf (mm) & 16.56 & $1.0-2.0$ & 243.4 \\
Number of culms & 13.08 & $96.2-370.9$ & 4.8 \\
Length of cauline leaf (mm) & 12.91 & $3.6-6.3$ & 495.9 \\
Length of culm (mm) & 11.14 & $365.7-600.9$ & 487.0 \\
Number of vegetative stems & 11.06 & $249.4-717.5$ & 27.3 \\
Number of spikelets in the panicle & 8.70 & $21.0-42.9$ & 107.9 \\
Diameter of tuft (mm) & 3.74 & $80.2-147.9$ & 0.8 \\
Thickness of leaf blade (mm) & 3.41 & $0.7-1.0$ & 1.5 \\
Width of leaf blade (mm) & 3.02 & $1.0-2.2$ & \\
\hline
\end{tabular}

leaved grass with relatively rigid and thin leaves (Tab. 2).

\section{Evaluation of qualitative traits}

Each species or even variety exhibits a characteristic habit and a specific shape. Habitat and anthropogenic factors may modify to a bigger or lesser extent the size of the shoot and its organs in individual plants. Yet, the plant habit is a constant feature (Trinklein 2006). The observations and the presented results show that the individuals with shorter and more

Table 3. Descriptions, abbreviations and attributes of qualitative characteristics and their frequencies in Festuca trachyphylla

\begin{tabular}{|c|c|c|}
\hline Trait & Class & $\begin{array}{l}\text { Number } \\
\text { of plants }\end{array}$ \\
\hline \multirow{2}{*}{$\begin{array}{l}\text { Plant growth } \\
\text { habit }\end{array}$} & round & 21 \\
\hline & umbrella-like & 3 \\
\hline \multirow{2}{*}{$\begin{array}{l}\text { Greenness index } \\
\text { of leaf blade }\end{array}$} & $33-38$ & 17 \\
\hline & $39-45$ & 7 \\
\hline \multirow{2}{*}{$\begin{array}{l}\text { Winter } \\
\text { greenness** }\end{array}$} & $6-8$ & 14 \\
\hline & 9 & 10 \\
\hline \multirow{2}{*}{$\begin{array}{l}\text { Culm } \\
\text { colour }\end{array}$} & green & 9 \\
\hline & purple & 15 \\
\hline \multirow{2}{*}{$\begin{array}{l}\text { Waxy coating } \\
\text { on the leaf blade }\end{array}$} & present & 18 \\
\hline & absent & 6 \\
\hline \multirow{2}{*}{$\begin{array}{l}\text { Flowering } \\
\text { periods }\end{array}$} & May 10-15 & 16 \\
\hline & May 16-21 & 8 \\
\hline \multirow{2}{*}{$\begin{array}{l}\text { Plant condition } \\
\text { after } 8 \text { years }\end{array}$} & good & 20 \\
\hline & weak & 4 \\
\hline
\end{tabular}

*in SPAD, **in 1-9 scale rigid leaves had a round habit, and those with longer leaves had an umbrella-like shape (Tabs 2 and 3).

Analyses of the chlorophyll content in the plants based on the optical method are useful in examinations of plant colour, vitality, and resistance to thermal and humidity stress. The chlorophyll content is an indicator of the current condition of a plant or its resistance to adverse environmental factors. Thermal stress and low fertility of the habitat reduce plant vitality and chlorophyll levels (Pagola et al. 2009). The interesting research conducted by Kozłowski et al. (2001) involved a comparison of the results of the assessment of the chlorophyll content in the Lolium multiforum leaf blades with the chemical method (7.86 $\mathrm{mg} \mathrm{g}^{-1}$ d.m.) and with the results obtained using a chlorophyll meter (76.9 SPAD); the comparison revealed a similarity in the results obtained using both methods. In the present work, the greenness index of the leaf blade for the examined individuals ranged from 33 to 45 SPAD. For a majority of the individuals, the greenness index did not exceed 39 SPAD (Tab. 3). According to the results of investigations carried out by Gàborčik (2003) and Olszewska et al. (2008), who classified individual grass species in terms of the greenness index of the leaf blade, the genus Festuca was given a high mark of 44.3 SPAD on average, compared with Lolium perenne at 41.5, Lolium multiforum at 40.4, Dactylis glomerata at 38.4, Phleum phleoides at 34.4 and Poa pratensis at 29.3 SPAD.

Colour stability and winter greenness are particularly favourable traits for lawn and ornamental varieties (Prończuk 1993). The level of 
winter greenness for the $F$. trachyphylla individuals ranged between six and nine of the applied scale. More than half of the plants were assessed in January and reached a grade of eight or higher (Tab. 3).

Anthocyanins have a substantial impact on grass colour. They are mainly contained in the nodes, leaf sheaths of the lower parts of the shoot, and in inflorescences, particularly in their rachis and rachillae. Light and the ambient temperature affect the anthocyanin content. Temperature decline triggers their production (Kozłowski 2003). The purple colour of the stem was visible in a majority of the individuals and was enhanced during the development of the stem (Tab. 3).

Plant colour, especially the colour of its leaf blades, may be modified by the presence of wax deposits and trichomes on the surface of the leaves and culms (Pawlus 1983, Wilkinson and Stace 1991). The wax coating on the leaf blade exhibited low stability and was modified by environmental factors. The leaf blades of the selected individuals were mostly covered with a waxy coating of varied thickness (Tab. 3).

The flowers in F. trachyphylla did not have a high decorative value. They were very poor in terms of colour, as yellow anthers were their only vivid element. The flowering period lasted 12 days on average; the onset was recorded on 10 May, and towards the end on 21 May. Most individuals flowered in the first half of May. After eight years of the study, most of the plants were in good condition (Tab. 3).

Two interesting ecotypes of plants were observed among the individuals under study: (1) densely tufted, with short, rigid leaves covered by a waxy coating, purple culms, elongated inflorescences, and a rounded habit; (2) densely tufted with long, arching, glossy leaves covered with a small amount of waxy coating, green glossy culms, elongated or round inflorescences, and an umbrella-like habit. The other individuals represented intermediate forms of the selected types and did not exhibit desirable decorative features.

The high decorative values of $F$. trachyphylla and their variability cannot be ascribed to a mere landscaping function. The selected types should be referred to as ornamental grasses in the further process of breeding. The valuable decorative traits of the selected plant types distinguish them among the cultivated fescues from the group $F$. ovina agg. The most decorative features of the selected ecotypes include the shape and colour of the leaves and the plant habit. The selected plants produced dense tufts, which nicely complement stones and modern architecture. They may be grown as very durable bedding plants. They are not difficult to cultivate. They grow best in full sunlight and moderately fertile soil.

\section{CONCLUSIONS}

1. The F. trachyphylla ecotypes originating from Lubelszczyzna differed the most in the length of the leaf blade, length of the panicle, width and length of the cauline leaf, and the number of culms. A high variability between the researched ecotypes was found for five qualitative traits: culm colour, winter greenness, flowering periods, greenness index of leaf blade, and the waxy coating on the leaf blade.

2. F. trachyphylla is a morphologically variable species, which offers the possibility of a selection of its most interesting types with desirable decorative features. Due to its high ornamental value, $F$. trachyphylla should be included in the assortment of ornamental grasses.

\section{ACKNOWLEDGEMENTS}

I would like to thank Professor Bogusław Sawicki for help in creating the collection.

\section{REFERENCES}

Conert H.J., 1996. Festuca. In: Illustrierte Flora von Mitteleuropa 1(3). G. Hegi and Paul Parey (eds), Berlin-Hamburg: 561-633.

DARKE R., 1999. The color encyclopedia of ornamental grasses: sedges, rushes, restios, cat-tails, and selected bamboos. Timber Press, Portland, Oregon.

Davidson E.G., Gobin S.M., 1998. Evaluation of ornamental grasses for the Northern Great Plains. J. Environ. Hort. 16(4): 218-229.

DĄBRowsKA A., 2010. Evaluation of suitability of Festuca rubra L. and F. nigrescens Lam. ecotypes as a material for lawn grass breeding. Folia Hort. 22(1): 51-56.

DOMAŃSKI P., 1998. Metodyka badania wartości gospodarczej odmian (WGO) roślin uprawnych. COBORU, Słupia Wielka 1: 1-35.

GÀBORČIK N., 2003. Relationship between contents of chlorophyll $(\mathrm{a}+\mathrm{b})$ (SPAD values) and nitrogen of some temperate grasses. Photosynthetica 41(2): 285-287.

King M., Oudolf P., Chatto B., 1998. Gardening with grasses. Timber Press, Portland, Oregon.

KozŁowski S., 2003. Grasses in the Polish landscape. In: Problems of grass biology. L. Frey (ed.), W. Szafer 
Institute of Botany, Polish Academy of Sciences, Kraków: 201-218.

KozŁowski S., Goliński P., GolińsKA B., 2001. Chlorophyll dyes as usability indicators of grass species and cultivars. Zesz. Probl. Post. Nauk Roln. 474: 215-223.

Markgraf-Dannenberg I., 1980. Festuca L. In: Flora Europaea 5. T.G. Tutin, V.H. Heywood, N.A. Burges, D.M. Moore, D.H. Valentine, S.M. Walters and D.A. Webb (eds), Cambridge University Press, Cambridge: 125-153.

Markwell J., Osterman J.C., Mitchell J.L., 1995. Calibration of the Minolta SPAD-502 leaf chlorophyll meter. Photosyn. Res. 46: 467-472.

Olszewska M., Grzegorczyk S., Alberski J., BaŁuchMalecka A., Kozikowski A., 2008. Effect of copper deficiency on gas exchange parameters, leaf greenness (SPAD) and yield of perennial ryegrass (Lolium perenne L.) and orchard grass (Dactylis glomerata L.). J. Elementol. 13(4): 597-604.

Pagola M., Ortiz R., Irigoyen I., Bustince H., Barrenechea E., Aparicio-Tejo P., 2009. New method to assess barley nitrogen nutrition status based on image colour analysis. Comparison with SPAD-502. Comput. Electron. Agric. 65: 213-218.

Pawlus M., 1983. Taxonomy and distribution of the Festuca ovina group in Poland. Fragm. Flor. Geobot. 29(2): 219-295.

PrończUK S., 1993. System oceny traw gazonowych. Biul. IHAR 186: 127-132.

Trinklein D.H., 2006. Ornamental grasses. Mu guide. Horticultural. Published by mu extension, University of Missouri-Columbia G6661. Available online at http://extension.missouri.edu/p/G6661; cited on 09 May 2012.

Walters S.M., Brady A., Brickell C.D., Cullen J., Green P.S., Lewis J., 1984. The European Garden Flora: Volume 2, Monocotyledons: Juncaceae to Orchidaceae: A manual for the identification of plants cultivated in Europe, both out-of-doors and under glass. Cambridge Univ. Press, Cambridge.

Wilkinson M.J., Stace C.A., 1991. A new taxonomic treatment of Festuca ovina L. aggregate (Poaceae) in the British Isles. Bot. J. Linn. Soc. 106: 347-397.
OCENA WARTOŚCI DEKORACYJNEJ DZIKO ROSNĄCYCH OSOBNIKÓW FESTUCA TRACHYPHYLLA (HACK.) KRAJINA W POŁUDNIOWO-WSCHODNIEJ CZĘŚCI POLSKI

Streszczenie: W latach 2004-2011 przeprowadzono ocenę wartości dekoracyjnej 24 osobników Festuca trachyphylla pochodzących $\mathrm{z}$ naturalnych siedlisk Lubelszczyzny. Wybrane rośliny o pożądanych cechach ozdobnych pobrano w formie sadzonek i wysadzono na poletkach doświadczalnych w Ogrodzie Botanicznym Uniwersytetu Marii Curie-Skłodowskiej w Lublinie, stwarzając im jednolite warunki siedliskowe. W latach badań przeprowadzono analizę 18 cech morfologicznych określających wartość ozdobną traw: 11 ilościowych (długość i liczba źdźbeł, długość kwiatostanu, liczba kłosków w kwiatostanie, liczba pędów wegetatywnych, długość, szerokość i grubość blaszki liściowej, długość i szerokość liścia flagowego, średnica kęp) i 7 jakościowych (pokrój rośliny, indeks zieloności blaszki liściowej (SPAD), zimozieloność, barwa źdźbeł, owoszczenie blaszki liściowej, okres kwitnienia, kondycja roślin po 8 latach uprawy). Na podstawie analizy cech ilościowych i jakościowych, stwierdzono, że $F$. trachyphylla jest gatunkiem zmiennym morfologicznie. Zmienność ta przejawiała się przede wszystkim w budowie kwiatostanu, długości blaszek liściowych oraz liczbie pędów, na co wskazują wyniki analizy statystycznej ANOVA. Szeroki zakres zmienności cech dotyczył również pokroju roślin, barwy liści i pędu, owoszczenia liści oraz pory kwitnienia. Wysoka zmienność morfologiczna tego gatunku pozwoliła na wyodrębnienie spośród badanych osobników, dwa ciekawe typy roślin, wyróżniające się korzystnym doborem cech ozdobnych. Największą ozdobą wybranych ekotypów jest kształt i barwa liści oraz pokrój rośliny.

Received May 10, 2012; accepted November 29, 2012 